\title{
PENGEMBANGAN JEJARING BISNIS BERBASIS MEDIA DIGITAL SEBAGAI RESILIENSI PEREMPUAN DEMI KETAHANAN EKONOMI KELUARGA
}

\author{
METHA MADONNA \\ madonna@apps.ipb.ac.id
}

Program Studi Komunikasi Pembangunan Institut Pertanian Bogor

\begin{abstract}
ABSTRAK
Krisis ekonomi dan pandemi Covid-19 membuat masyarakat lapisan sosial bahwa rentan miskin. Sejumlah program perlindungan sosial telah diluncurkan Pemerintah seperti Bantuan Langsung Tunai (BLT), subsidi listrik, hingga kuota internet guna menunjang Pendidikan Jarak Jauh (PJJ). Namun belum menyentuh seluruhnya tepat sasaran dan mencukupi bagi mereka yang terdampak resesi. Upaya perempuan, ibu rumah tangga, dalam merintis bisnis berbasis media digital menjadi penting dikaji dalam perspektif perencanaan sosial partisipatif. Resiliensi perempuan dalam penguasaan bisnis berbasis komunikasi digital dimotivasi membangun ketahanan ekonomi keluarga. Implikasi: terjadi pemberdayaan perempuan dalam bentuk partisipasi ibu rumah tangga dalam bisnis online untuk membantu perekonomian keluarga.
\end{abstract}

Kata kunci: Jejaring bisnis digital, resiliensi, perempuan, ekonomi keluarga.

\begin{abstract}
The Economic crisis and Covid-19 pandemic made people in society realize that they're vulnerable and poor. Many programs of social protection have already been launched by the government like Cash Transfer (BLT), electricity subsidies, and internet kuota to support distance education (PJJ). But it hasn't touched all on target and sufficient for those affected by the recession. A husband losing their job or business failure forces women to find additional alternatives. Face to face restrictions, avoid virus and digital media transformation demanding women to adapt (resilience) develop network commercials via the internet. Attempting women, housewives, in starting business based on digital media became important to review in the perspective of participatory social planning. Purpose: Research exploring concept and activity resilience women for family economic resilience. Methodology: Paradigm constructivism research, participatory method through research and practice online business. Hasil: after training and practicing business through digital communication media, women with housewife status can develop relationship networks or connectivity. Resilient women in mastering business-based digital communication in motivation develop family economic resilience. Implication: There empowerment women in participant housewife in online business for helping family economy.
\end{abstract}

Keyword: Digital business network, resilience, women, family economy 


\section{PENDAHULUAN}

\section{Latar Belakang Masalah}

Krisis ekonomi global sebagai dampak pandemi Covid-19 telah berdampak langsung pada kondisi keuangan rumah tangga. Keluarga sebagai kelompok masyarakat terkecil dengan pendapatan rendah, sehingga rentan akan mengalami kemiskinan. Berdasarkan laporan Bank Dunia, Indonesia termasuk negara berpendapatan rendah bersama lima negara lainnya setelah di bawah Nepal dan Tanzania, namun belum lama ini Bank Dunia menaikkan peringkat Indonesia sebagai negara dengan pendapatan menengah ke atas (upper middle income) dari sebelumnya pendapatan menengah ke bawah (lower middle income) (Fauzia, 2020). Dimana sebelumnya transaksi perdagangan terus mengalami penurunan, penghentian operasional perusahaan dan pabrik akibat industri mengalami stagnasi, berujung pada Pemutusan Hubungan Kerja (PHK). Banyak kepala rumah tangga harus kehilangan pekerjaan sementara biaya hidup terus meningkat, imbasnya ekonomi keluarga pun mengalami keterpurukan.

Selain jumlah pasien Covid terus meningkat, jumlah pengangguran pun semakin banyak hal ini senada dengan yang dikatakan Menteri Ketenagakerjaan Ida Fauziyah angka pengangguran di Indonesia selama Indonesia mengalami pandemic Covid-19 meningkat dari sebelumnya 4, 9 persen menjadi 7 persen atau 9,7 juta orang tidak mempunyai pekerjaan. Padahal sebelumnya pihak pemerintah sempat menurunkan angka pengangguran sebanyak 4,9 persen namun akibat Covid jumlah pengangguran kembali melambung tinggi (Zamani, 2021).Guna mengatasi kemiskinan pihak Pemerintah berupaya dengan diluncurkannya sejumlah program perlindungan sosial seperti Bantuan Langsung Tunai (BLT), subsidi upah bagi pekerja yang terkena PHK, subsidi listrik dan sembako murah bagi keluarga pra sejahtera termasuk bantuan kuota internet bagi pendidik dan pelajar dalam rangka mensukseskan Pembelajaran Jarak Jauh (PJJ). Biaya perlindungan sosial untuk tahun 2021 mencapai Rp408,8 triliun dari Anggaran Pendapatan dan Belanja Nasional (APBN).

Program proteksi sosial tersebut sesungguhnya pada sisi lain bertujuan mempertahankan daya belanja masyarakat. Menteri Keuangan Sri Mulyani mengakui sejumlah kebijakan proteksi mempertahankan belanja rakyat dan aktivitas transaksi keuangan serta mempertahankan ekosistem perekonomian nasional. Namun pada kenyataannya sejumlah program proteksi sosial tersebut belum sepenuhnya mencapai sasaran sesuai peruntukan, masih ada yang kekurangan dan ada yang semestinya tidak menerima jadi menerima bantuan. Dikatakan anggota DPRD DKI Lukmanul Hakim bahwa bantuan tunai selain turunnya tidak tepat waktu masih dan masih ada yang tidak menerima, padahal menurutnya di kondisi Covid-19 seperti saat ini tentunya masyarakat banyak mengalami kendala di bidang ekonomi (Hantoro, 2021).

Seiring terus melonjaknya harga kebutuhan pokok. Keluarga dengan kategori ekonomi kelas menengah di ambang kemiskinan, sebaliknya keluarga dengan kategori pra sejahtera dan miskin terus bertambah banyak. Ancaman gizi buruk, anak putus sekolah, pengangguran dan angka kriminalitas terus bertambah.Menghadapi situasi penuh ketidakpastian saat pandemi Covid-19 yang disusul krisis dan resesi ekonomi, 
mendesak kaum perempuan dengan status ibu rumah tangga untuk mencari alternatif sumber pendapatan lain. Berdagang kecil kecilan, membantu memasarkan produk pihak lain (reseller), menjual jasa sebagai pencuci pakaian, menjadi pengasuh anak dan sebagainya terus diupayakan perempuan demi kelangsungan perekonomian keluarga.

Selama perempuan selalu dianggap nomor dua dalam keluarga bahkan bisa dan itu terjadi di berbagai sektor seperti di ekonomi, politik, sosial bahkan budaya. Pergeseran peranan perempuan menjadi nomor dua akibat ketidak-terlibatan perempuan di dalam usaha pemenuhan kebutuhan hidup. Dimana perkembangan masyarakat berfokus pada kegiatan meramu dan menetap kemudian laki-laki mengambil alih peran perempuan, kemudian peran perempuan bergeser ke sektor domestic dalam mengurusi keluarga. Namun dampak dari Covid-19 peranan perempuan kembali muncul ke permukaan seperti yang terjadi di Rungkut Lor II kampung kue dan kampung dengan jumlah Covid tertinggi. Namun perekonomian rakyat masih bisa berjalan dengan adanya penjualan kue dan itu satusatunya sumber pendapatan keluarga yang diperjuangkan oleh para pelaku UMKM di kampung tersebut (Sari et al., 2020).

Upaya perempuan dalam ketahanan ekonomi keluarga menghadapi kendala dibatasi aktivitas interaksi tatap muka yang bertujuan mengurangi risiko penularan virus. Begitu juga prospek berdagang turut melemah seiring daya beli masyarakat menurun dan jumlah pembeli terus berkurang karena jarang konsumen lalu lalang menyusul pemberlakuan Work From Home (WFH), sekolah daring dan sejenisnya. Pilihannya adalah berbisnis memanfaatkan Teknologi Informasi Komunikasi (TIK). Meskipun perdagangan atau bisnis berbasis internet atau disebut e-commerce lebih banyak perempuan yang menjadi konsumen, namun sejak terjadi Covid posisi perempuan justeru menjadi penjual dan bisa dikatakan banyak pemain baru di bidang ini.

\section{Rumusan Masalah}

Proses adaptasi perempuan ibu rumah tangga terhadap inovasi teknologi menjadi penting untuk dikaji. Muncul beberapa pertanyaan penelitian yaitu:

1. Bagaimana perempuan beradaptasi dengan TIK?

2. Bagaimana perempuan mengembangkan jejaring bisnis berbasis komunikasi digital?

3. Bagaimana perempuan berpartisipasi dalam perubahan sosial?

\section{Tujuan Penelitian}

Penelitian mengeksplorasi konsep dan aktivitas resiliensi perempuan demi ketahanan ekonomi keluarga. Serta memberdayakan kaum ibu rumah tangga agar ikut berpartisipasi dalam proses pembangunan nasional.

\section{Manfaat Penelitian}

Secara praktis penelitian partisipatori ini membantu memberdayakan masyarakat khususnya perempuan agar dapat menjalankan bisnis online melalui media digital. Sekaligus meningkatkan partisipasi kaum perempuan dalam pembangunan komunitas. Secara teoritis penelitian ini merepresentasikan perubahan sosial dalam perspektif teori perencanaan sosial partisipatif, yaitu sebuah proses pembangunan yang melibatkan masyarakat bukan saja sebagai objek melainkan sebagai subjek.

\section{TINJAUAN PUSTAKA}

\section{Perencanaan Sosial Partisipatif}

Perencanaan pembangunan partisipatif merupakan perencanaan yang bertujuan melibatkan kepentingan rakyat dimana dalam prosesnya melibatkan masyarakat baik itu secara langsung maupun tidak langsung. Perencanaan ini merupakan pola 
pendekatan perencanaan pembangunan yang melibatkan peran serta masyarakat yang bukan saja sebagai objek tetapi juga subyek pembangunan, sehingga nuansa yang dikembangkan dalam perencanaan pembangunan benar-benar dari bawah (bottom-up approach) (Maripah, 2017).

Kontribusi masyarakat dalam pembangunan khususnya kaum perempuan terbuka lebar di saat sistem kehidupan berbangsa justeru berpijak pada ekosistem yang melibatkan setiap komponen bangsa terutama pada sektor perekonomian yang terbangun atas andil tiap-tiap kegiatan usaha masyarakat di dalamnya, rantai perekonomian nasional dibangun di atas peran serta aktivitas ekonomi individu di dalamnya. Maka partisipasi kaum perempuan dalam mendukung pembangunan nasional dapat diimplementasikan dalam bentuk partisipasinya dalam kegiatan bisnis.

\section{Motivasi Sosial Partisipatif}

Motivasi berasal dari bahasa latin yaitu 'movere' yang berarti bergerak pada dasar katanya adalah 'motif' jadi bisa dikatakan sebagai motivasi yang ada di dalam pribadi seseorang yang mendorong keinginan individu untuk melakukan berbagai kegiatan tertentu atau bisa mengacu pada dorongan atau usaha untuk mencapai suatu tujuan atau memuaskan kebutuhan hidup seseorang. Ada dua metode motivasi yaitu motivasi langsung dan tidak langsung Sedangkan menurut Djamarah (2002: 123) ada tiga fungsi motivasi, yaitu 1. Motivasi sebagai pendorong perbuatan. 2. Motivasi sebagai penggerak perbuatan. 3. Motivasi sebagai pengarah perbuatan (Mandasari et al., n.d.).Selain itu keterlibatan masyarakat dalam pembangunan bisa karena dengan sengaja dilibatkan atau atas inisiatif sendiri dengan berlatar motivasi diri.

Keterdesakan atas tekanan ekonomi dan kebutuhan yang terus meningkat, merupakan motivasi kaum perempuan di kota-kota besar seperti di Bekasi Jawa Barat, tentunya jadi alasan untuk ambil bagian dalam perdagangan berbasis media digital. Dorongan kuat untuk membantu suami yang tidak lagi produktif, memenuhi biaya sekolah dan belanja makanan pokok adalah alasan partisipan yang tidak memiliki pekerjaan tetap (formal). Motivasi besar lainnya dari partisipan peserta pelatihan berbisnis online yaitu tertantang menguasai aplikasi media sosial, teknik dan cara mengoperasikan aplikasi bisnis online.

\section{Pengembangan Jejaring Bisnis}

Namun keberhasilan usaha di saat pandemic tentunya memerlukan pengembangan jaringan bisnis mengingat salah satu faktor penentu keberhasilan dalam berwirausaha adalah adanya akses ke jaringan sosial (Zampetakis dan Kanelakis, 2010). Castells (2010, p. 500) yang menjelaskan bahwa aktivitas manusia semakin terorganisir oleh jaringan. Jaringan merupakan morfologi sosial baru dari masyarakat kita, dan difusi logika jaringan secara substansial memodifikasi operasi dan hasil dalam proses produksi, pengalaman, kekuatan dan budaya. Foley (2008) mengusulkan bahwa jaringan sosial dapat memiliki pengaruh yang kuat pada aktivitas kewirausahaan karena pengusaha yang tertanam dalam konteks sosial yang mempengaruhi keputusan mereka (Adawiyah, n.d.).

Fakta empiris menunjukkan bahwa kaum perempuan sebagian besar adalah pengguna aktif media sosial dan sebagai representasi pergaulan mereka di dunia maya. Pertemanan dan interaksi di media sosial seperti Facebook, Twitter, WhatsApp dan sebagainya merupakan potensi besar dalam upaya membangun jejaring bisnis.Peluang keberhasilan bisnis online dijelaskan instruktur dalam pelatihan tersebut adalah ditentukan banyaknya pengikut (followers). Selain followers atau relasi pengembangan 
jejaring bisnis juga dipengaruhi inovasi pembentukan citra diri maupun produk.

\section{METODOLOGI PENELITIAN}

\section{Waktu dan Tempat Penelitian}

Pelatihan dan praktik dilaksanakan selama Agustus dan September 2020 di Kelurahan Marga Mulya dan Kelurahan Kaliabang Tengah, Kecamatan Bekasi Utara, Kota Bekasi, Jawa Barat.

\section{Metode dan Pendekatan Penelitian}

Paradigma penelitian konstruktivisme dengan pendekatan kualitatif. Metode penelitian yang digunakan adalah Participatory Action Research (PAR) berupa kegiatan memberdayakan perempuan agar mampu berbisnis melalui media komunikasi digital. Selanjutnya kegiatan (studi deskriptif kualitatif) analisis dilakukan secara mandiri setelah pelaksanaan pelatihan dan pendampingan kepada kaum perempuan tersebut, tidak seluruh peserta perempuan dijadikan sumber informasi (informan) namun ditentukan secara purposive yaitu ibu rumah tangga yang memiliki kegiatan usaha sampingan seperti reseller, penjual aneka kuliner, pedagang kelontong atau penjual jasa. Dengan demikian dapat dideskripsikan implikasi dan aplikasi kegiatan pemberdayaan masyarakat khususnya kaum perempuan.

\section{Populasi dan Sampel}

Subyek dalam penelitian (populasi) ini ibu rumah tangga di Kelurahan Marga Mulya sebanyak 15 dan di Kelurahan Kaliabang Tengah sebanyak 25 ibu rumah tangga, sebagai peserta Participatory Action Research (PAR). Sedangkan yang terpilih sebagai informan yang dilakukan secara purposive sampling yaitu lima ibu tangga untuk studi deskriptif kualitatif.

\section{Teknik Pengumpulan Data}

Pengumpulan data dilakukan melalui observasi dan wawancara mendalam kepada informan yang telah ditentukan sebelumnya (purposive) kemudian dilengkapi dengan data sekunder berupa dokumentasi dari berbagai bahan publikasi, berita maupun jurnal ilmiah.

\section{PEMBAHASAN}

\section{Resiliensi Perempuan untuk Ketahanan Ekonomi Keluarga}

Resiliensi ekonomi perempuan merupakan proses perubahan sosial yang dialami kaum perempuan dalam perspektif ekonomi dan gender. Resiliensi menempatkan perempuan dalam posisi strategis sebagai Sumber Daya Manusia (SDM) multi talenta yaitu meningkatkan kualitas kesejahteraan keluarga sekaligus berkontribusi memperbaiki finansial keluarga.

Pernyataan Rektor Institut teknologi dan Bisnis Ahmad Dahlan Jakarta, Mukhaer Pakkanna bahwa perempuan dituntut mampu beradaptasi dengan teknologi agar dapat membuka peluangnya dalam kegiatan media digital, pastinya perlu disambut serius kaum perempuan Indonesia. Apalagi tidak dapat dipungkiri jika perempuan di Tanah Air adalah penggunaan perangkat digital paling konsumtif meskipun menurut laporan International Telecommunication Union (ITU) 2017 Lin Taylor mengatakan kalau secara global pengguna perempuan lebih rendah 12 persen dibandingkan pengguna laki-laki (media indonesia, 21 Mei 2021).Maka tidaklah sulit mengarahkan orientasi konsumsi gadget mereka ke arah yang lebih produktif (Pakkanna, 2021).

Resiliensi perempuan yang kemudian diikuti dengan fasilitas atau dukungan finansial khusus, Mukhaer menyebutnya ilusi keuangan, dipastikan menjadi stimulasi agar berdayanya perempuan 
sebagai pelaku ekonomi produktif. Dukungan finansial berupa pinjaman ringan atau insentif modal dari perbankan maupun Pemerintah, kemudian diarahkan ada kegiatan ekonomi berbasis digital yang mudah diaplikasikan oleh perempuan.

Resiliensi yang dikolaborasikan dengan inklusi keuangan, di ujungnya memberi ruang bagi perempuan untuk berkontribusi pada pertumbuhan ekonomi nasional. Bahkan bisa jadi aktivitas perempuan dalam media digital yang lebih agresif mengingat secara kuantitas dan kapasitas perempuan lebih berpotensi. Pemberdayaan perempuan dalam sektor ekonomi pada akhirnya memperbaiki disparitas gender yang selama ini disandang perempuan, di antaranya dilabelisasi sebagai shopper.

Partisipasi dan kontribusi perempuan dalam aktivitas ekonomi berbasis digitalisasi dan internet, merupakan sebuah fenomena perubahan sosial yang perlu disikapi positif dan optimistis. Resiliensi dan inklusi keuangan apabila terlaksana efektif saat membawa kaum perempuan sebagai salah satu pilar kebangkitan perekonomian bangsa.

\section{Pelatihan Penguasaan Media Digital}

Upaya membangun partisipasi masyarakat dalam pembangunan, khususnya kaum perempuan dilakukan dengan memberikan pelatihan dan pendampingan dalam penguasaan media komunikasi digital sebagai sarana mengembangkan jejaring bisnis. Melalui peningkatan dan kemampuan dan keterampilan mengoperasikan berbagai aplikasi di media digital, diharapkan para perempuan di wilayah Bekasi dapat memperbaiki perekonomian keluarga.

Pelatihan di Kelurahan Marga Mulya, Kecamatan Bekasi Utara, Kota Bekasi, Jawa Barat berupa penyusunan, penyuntingan dan penyebaran newsletter melalui internet. Para peserta kegiatan dalam format workshop tersebut dibimbing agar mampu membuat newsletter bermuatan informasi, promosi dan rilis soal produk atau jasa, sekaligus menjaga relasi dengan mitra maupun pelanggan.

Pembelajaran tentang bagaimana merancang newsletter yang baik, informatif dan komunikatif tersebut dilakukan dalam suasana belajar yang interaktif dalam bentuk diskusi dan praktik. Pasca pelatihan dan pendampingan selama tiga kali pertemuan dengan durasi masing-masing dua jam, para peserta telah dapat membuat newsletter yang memenuhi standar dunia Public Relation yang segera diaplikasikasikan melalui media sosial seperti WhatsApp (WA) dan Instagram.

Kegiatan menggalang partisipasi perempuan khususnya ibu rumah tangga berikutnya dilakukan melalui workshop penggunaan media sosial sebagai perluasan pasar yang diselenggarakan di Kelurahan Kaliabang, Kecamatan Bekasi Utara, Kota Bekasi Jawa Barat. Para ibu rumah tangga diajarkan memanfaatkan berbagai fitur di media sosial dengan tujuan membuat pesan yang menarik, menyentuh dan dengan kata-kata dan gambar yang memikat sehingga orang tertarik untuk menjalin kontak. Fokus pelatihan pada media sosial WA dan Instagram (IG) karena di keduanya paling mudah dan kerap digunakan (familiar) oleh para ibu rumah tangga yang sehariharinya. Mereka kebetulan memiliki usaha sampingan sebagai reseller, pedagang kelontong, menjual aneka kuliner maupun pemberi jasa sehingga sangat antusias dengan pelatihan tersebut.

Pembelajaran dilaksanakan memanfaatkan perangkat media digital milik peserta, pelatihan diberikan secara personal dan bergiliran. Instruktur pembimbing peserta mengaplikasikan hasil ceramah dan diskusi di kelas. Hasilnya dalam dua kali pertemuan tatap muka dengan durasi 
masing-masing tiga jam yang diawali dengan ceramah mengenai peluang bisnis memanfaatkan peluang media digital yang dilanjutkan dengan praktik secara langsung, sampai para peserta telah mampu mengaplikasikan teknik pemasaran berikut penyusunan konten, pesan yang menarik, menyentuh dan informatif.

\section{KESIMPULAN DAN SARAN}

\section{Kesimpulan}

Selanjutnya setelah kegiatan partisipatif di lapangan berlangsung, analisis implikasi kegiatan sekaligus evaluasi program dilaksanakan melalui observasi dan interview secara interpersonal kepada para perempuan peserta pelatihan. Secara spesifik peserta pelatihan yang dituju sebagai informan adalah para ibu rumah tangga yang masih memiliki suami dan anak (tanggungan). Sebetulnya terdapat juga beberapa perempuan pelaku bisnis namun tidak termasuk dalam kategori ibu rumah tangga dengan beban, melainkan single parent atau belum berkeluarga namun informasinya ditambahkan kepada deskripsi respon perempuan pebisnis secara umum.

Hasil observasi dan interview menunjukkan tidak ada hambatan atau kendala bagi kaum perempuan khususnya para ibu rumah tangga untuk mengoperasikan perangkat media digital. Begitu juga untuk mengoptimalkan fitur dan segala fasilitas pendukung di media sosial seperti WA dan IG yang ternyata telah banyak dimanfaatkan para ibu untuk bersosialisasi.

Simpulan dari serangkaian interview kepada peserta perancangan newsletter, kendala terdapat pada penyusunan pesan namun untuk mengunggah ke media sosial tidak ada masalah. Para terkendala perbendaharaan bahasa, efektivitas kalimat dan dan narasi yang terstruktur. Permasalahan yang sama dialami para ibu rumah tangga peserta pelatihan pengembangan bisnis lewat WA dan IG, mereka mengalami kesulitan untuk menyusun konten yang menarik, menyentuh dan informatif.

Sebaliknya secara keseluruhan hasil pelatihan dan pembimbingan penguasaan media digital kepada kaum perempuan di Bekasi agar mampu mengembangkan jejaring bisnisnya, dinilai berhasil oleh para peserta sendiri. Para ibu rumah tangga merasakan manfaat berupa bertambahnya jumlah calon pelanggan yang diindikasikan dengan penambahan kontak dan followers. Meski belum terjadi peningkatan transaksi yang drastis berupa pemesanan produk atau jasa yang ditawarkan para ibu rumah tangga, namun terjadi perbaikan nilai nominal yang diraih dibandingkan periode sebelumnya.

Pengembangan jejaring bisnis memanfaatkan media komunikasi digital telah memberikan harapan sekaligus solusi ketika interaksi terkendala pandemi. Kaum perempuan, terutama ibu rumah tangga punya kesempatan memperoleh pendapatan (income) tambahan melalui bisnis online berbasis internet sehingga dapat memperkokoh ketahanan ekonomi keluarga di masa resesi dan pandemi.

\section{Implikasi}

Penelitian dengan metode partisipatori ini memiliki dua aplikasi sekaligus yaitu memberikan pembekalan kepada perempuan agar mampu berkontribusi pada peningkatan pendapatan keluarga, minimal membantu mempertahankan kondisi perekonomian keluarga pada masa krisis. Implikasi berikutnya secara tidak langsung meningkatkan partisipasi perempuan dalam pembangunan nasional.

\section{Saran}

Pasca pemberian pelatihan dan praktik berbisnis melalui media komunikasi digital, perempuan dengan status ibu rumah tangga dapat mengembangkan jejaring relasional atau koneksitas mereka. 
Resiliensi perempuan dalam penguasaan bisnis berbasis media digital dimotivasi membangun ketahanan ekonomi keluarga. Resiliensi perempuan demi penyelamatan perekonomian keluarga merupakan wujud partisipasi aktif dan mandiri perempuan dalam pembangunan. Kontribusi besar perempuan dalam bisnis online bukan hanya sebagai konsumen tapi juga berpotensi sebagai pelaku industri kreatif. 


\section{DAFTAR PUSTAKA}

Adiwiyah, W. R. (n.d.). Strategi Pengembangan Jejaring Bisnis Kewirausahaan Pedesaan. Universitas Jenderal Soedirman.

http://jp.feb.unsoed.ac.id/index.php/sc a-1/article/viewFile/962/pdf_167

Fauzia, M. (2020). Selain Indonesia, Ada 6 Negara Lain yang Naik "Kelas" Menurut Bank Dunia. Kompas.Com. https://money.kompas.com/read/2020 /07/02/181010726/selain-indonesiaada-6-negara-lain-yang-naik-kelasmenurut-bank-dunia?page $=$ all

Hantoro, J. (2021). Bansos Tunai Belum Cair, Anggota DPRD DKI: Banyak Warga Mengeluh. Metro.Tempo.Co. https://metro.tempo.co/read/1441677/ bansos-tunai-belum-cair-anggotadprd-dki-banyak-wargamengeluh/full\&view=ok

Mandasari et al., N. A. (n.d.). Pengaruh Persepsi dan Motivasi Terhadap Partisipasi Masyarakat Desa Hutan Dalam Pengelolaan Hutan Bersama Masyarakat (PHBM) Di Kawasan BKPH Guwo. Fisip. Undip. https://media.neliti.com/media/public ations/135767-ID-pengaruh-persepsidan-motivasi-terhadap.pdf

Maripah. (2017). Perencanaan Pembangunan Partisipatif Dalam Penyusunan Rencana Pembangunan Jangka Menengah Desa (RPJMDES) Di Desa Pangkalan Baru Kecamatan Siak Hulu Kabupaten Kampar. Jom Fisip. https://media.neliti.com/media/public ations/208575-perencanaanpembangunan-partisipatif-dal.pdf

Pakkanna, M. (2021). Resiliensi Ekonomi Perempuan. Kompas.Id. https:/www.kompas.id/baca/opini/20 21/05/04/resiliensi-ekonomiperempuan/
Sari et al., E. K. (2020). Perempuan Pencari Nafkah Selama Pandemi Covid-19. Al-Madad, 4, 13-29. file $/ / / \mathrm{C}: / U s e r s / U S E R / D o w n l o a d s / 11$ 06-Article Text-4316-1-1020210110.pdf

Zamani, L. (2021). Pandemi Covid-19, Jumlah Pengangguran di Indonesia Naik 9,7 Juta Orang. Kompas.Com. 